EISSN: 2706 -7947 ISSN: 2077- 4613

DOI: 10.36632/mejas/2021.11.4.62

Journal homepage: www.curresweb.com

Pages: 823-831

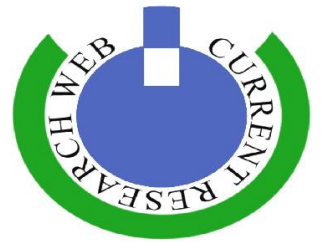

\title{
The allelopathic activity of the seed powder of two Lupinus albus species on growth and yield of Vicia faba plant and its associated Malva parviflora weed
}

\author{
Nadia K. Messiha, Ahmed S.A.A., Sanaa A. Mohamed, R.R. El-Masry and Kowther G. \\ El-Rokiek
}

Botany Department, National Research Centre, El Buhouth St., Dokki, Giza, Egypt, P.O. Box, 12622.

Received: 10 Sept. $2021 \quad$ Accepted: 05 Oct. $2021 \quad$ Published: 15 Oct. 2021

\begin{abstract}
Two pot experiments were carried out in the greenhouse of the National Research Centre of Egypt during winter seasons of 2017/2018 and 2018/2019 to study the allelopathic influence of bitter lupine seed powder (BLSP) or sweet lupine seed powder (SLSP) on the growth and yield of faba bean (Vicia faba L.) as well as their effect on the associated cheese weed (Malva parviflora). BLSP or SLSP at rates of ( 5 to $25 \mathrm{~g} / \mathrm{kg}$ soil) were incorporated into the soil surface of the pots. The obtained results indicated that all rates of both BLSP and SLSP significantly minimized fresh and dry weight of cheese weed at 40 DAS and at harvest. Cheese weed weight reduction increased by increasing the rate used of both lupine seed powder. The maximum reduction of cheese weed dry weight at both ages was recorded with BLSP at $25 \mathrm{~g}$ followed by SLSP at $25 \mathrm{~g}$ and BLSP at $20 \mathrm{~g} / \mathrm{kg}$ soil, which reached to $95.19,91.72$ and $90.38 \%$, respectively in dry weight of cheese weed at harvest comparing with mixed control. Reduced growth of cheese weed has been associated with increasing growth of faba bean plants. All rates of BLSP or SLSP cause significant increases on most faba bean growth parameters, yield and yield components. Generally, BLSP is more effective than SLSP in controlling cheese weed as well as increasing the growth, yield and yield components of faba bean plant. The allelopathic efficiency of BLSP and SLSP could be due to the presence of allelochemicals mainly alkaloids, phenolic and flavonoids compounds that could play an important role as a natural selective bioherbicide.
\end{abstract}

Keywords: Lupinus albus L. species, Vicia faba, Malva parviflora weed, Allelochemicals

\section{Introduction}

Faba bean (Vicia faba L.) is the major food and feed legume because of its nutritional value of the seeds. It is considered as one of the most important legumes in Egypt. It is one of the strategic crops due to its income to the farmers, it is important for soil fertility, human nutrition as a good source of vegetable protein and industrial purposes. Therefore, increasing faba bean production and improving its yield quality are the major targets to meet the demand of the increasing population, since faba bean constitutes a major part of the people's diet (Zeidan, 2002).

Weeds are serious pests that can damage most crops, since they compete the crop plants for light, moisture and other essential nutrients (Hussein, 2001). So, weeds reduce the quality and yield of crops and increase the cost of production (El-Rokiek et al., 2015; Ahmed et al., 2016 \& 2018; Messiha et al., 2018 and El-Masry et al., 2019).

Continuous and repeat use of herbicides cause toxicological or economical problems (Duke et al., 1999), thus, alternative natural herbicide become important to reduce the continuous use of synthetic herbicides and for the development of safer, alternative crop protectants (Mahmood and Cheema, 2004).

Allelopathy has beneficial or harmful effects on plants due to release of allelochemicals which are present in all plant tissues as leaves, stems, roots and seeds (Manikandan and Jayakumar, 2011 and Mohsin et al., 2016).These allelochemicals as phenolic compounds, flavonoids, terpenoids, alkaloids, amino acids and glucosinolates were found in different allelopathic plants (Einhellig, 2002 ; Velasco et al., 2008 and Ahmed et al., 2020). Nowadays, allelochemicals are used as biopesticides, bioherbicides 
and also as growth promoters. Allelochemicals are produced and released to the environment by different plants and different methods cause inhibitory or stimulatory effect depending on their types, concentration and the plant which respond these allelochemicals.

Many species within leguminosae family contain secondary plant products that have allelopathic potential (Bell and Charlwood, 1980, Rice, 1984 and Messiha, 2005). A limited number of studies have been conducted to investigate the influence of these allelochemicals on the growth of other leguminous plant as well as its effect on the growth and development of weeds (White et al., 1989; El-Dally and Soliman, 1997 and Messiha, 2005). Lupine (Leguminous plant) has an economical and agricultural value due to its potential as a source of protein or for pharmaceutical purposes, a green manure, or due to the high alkaloid content, as a natural component of plant pesticides (Sujak et al., 2006), so lupine possesses naturally occurring antimutagens and anticarcinogens. Lupine also contains flavonoids that play essential role as defense compounds against phytopathogens and herbivores (antifungal and antifeeding agents), Harborne, 1977; Ingham, 1982 and Dixon and Lamb, 1990.

The objective of this research is to define the allelopathic potentiality of Lupinus albus species (bitter and sweet) on the growth and yield of Vicia faba as well as the associated Malva parviflora weed.

\section{Materials and Methods}

In the greenhouse of the National Research Centre, Dokki, Giza, Egypt, two pot experiments were conducted during two successive seasons of 2017/2018 and 2018/2019, for studying the possibility of controlling cheese weed (Malva parviflora) growing with faba bean by using seed powder of bitter and sweet lupine (Lupinus albus). Faba bean (Vicia faba) cv. Giza 3 seeds, bitter and sweet lupine seeds as well as cheese weed seeds were obtained from Agriculture Research Centre, Giza, Egypt. Clean seeds of lupine were grinded to fine powder then the powder was immediately incorporated in the soil surface before sowing faba bean seeds at rates of $0.5,10,15,20$ and $25 \mathrm{~g} / \mathrm{kg}$ soil. Then seeds of faba bean and cheese weed were sown simultaneously and mixed thoroughly at a depth $2 \mathrm{~cm}$ in plastic pots filled with $2 \mathrm{~kg}$ soil. A randomized complete block design with nine replicates was used. The experiment includes 13 treatments as follows:

1- Faba bean alone (free control) 2-Cheese weed alone 3- Faba bean + cheese weed (mixed control)

4- Faba bean + cheese weed + bitter seed powder at $5 \mathrm{~g} / \mathrm{kg}$ soil

5 - Faba bean + cheese weed + bitter seed powder at $10 \mathrm{~g} / \mathrm{kg}$ soil

6 - Faba bean + cheese weed + bitter seed powder at $15 \mathrm{~g} / \mathrm{kg}$ soil

7 - Faba bean + cheese weed + bitter seed powder at $20 \mathrm{~g} / \mathrm{kg}$ soil

8 - Faba bean + cheese weed + bitter seed powder at $25 \mathrm{~g} / \mathrm{kg}$ soil

9- Faba bean + cheese weed + sweet seed powder at $5 \mathrm{~g} / \mathrm{kg}$ soil

10 - Faba bean + cheese weed + sweet seed powder at $10 \mathrm{~g} / \mathrm{kg}$ soil

11- Faba bean + cheese weed + sweet seed powder at $15 \mathrm{~g} / \mathrm{kg}$ soil

$12-$ Faba bean + cheese weed + sweet seed powder at $20 \mathrm{~g} / \mathrm{kg}$ soil

13- Faba bean + cheese weed + sweet seed powder at $25 \mathrm{~g} / \mathrm{kg}$ soil

The normal cultural practices of growing faba bean plants were followed especially fertilization and irrigation.

\subsection{Parameters studied}

I. Weed characters studied

From each treatment three replicates were collected at 40 days after sowing (DAS) and at harvest. Fresh and dry weight of the weed were recorded ( $\mathrm{g} / \mathrm{pot})$.

\subsection{Faba bean plants \\ I. Plant growth}

At 40 and 95 DAS samples of faba bean plants were collected from each treatment to determine: plant height $(\mathrm{cm})$, number of leaves /plant, number of branches/plant, fresh and dry weight / plant $(\mathrm{g})$. 


\section{Yield and yield components}

Samples of faba bean plants were taken at harvest from each treatment to determine: number of pods/plant, number of seeds/pod, weight of pods/plant (g), weight of seeds/plant $(\mathrm{g})$ and weight of 100 seeds $(\mathrm{g})$.

\subsection{Chemical analysis}

I. Determination of total phenols contents, flavonoids and alkaloids in the seed powder of bitter and sweet lupine

Total phenols and total flavonoids content in bitter and sweet lupine seed powder were determined according to Srisawat et al. (2010).

Total alkaloids content was determined in bitter and sweet lupine seed powder according to Harborne (2005).

\subsection{Statistical analysis}

All data were statistically analyzed according to Snedecor and Cochran (1980) and the treatment means were compared by using LSD at 5\% probability.

\section{Results}

\subsection{Weed growth}

The results in Table (1) and Fig. (1) Showed the potentiality of lupine (Lupinus albus) in controlling cheese weed (Malva parviflora) associated faba bean plants by different rates $(5-25 \mathrm{~g} / \mathrm{kg}$ soil) of both bitter (BLSP) and sweet (SLSP) lupine seed powder. The results indicated that all BLSP and SLSP rates significantly reduced fresh and dry weight of cheese weed at two growth ages (40 DAS and harvest) as compared to the mixed control. In this respect, bitter lupine seed powder (BLSP) was more effective than sweet lupine seed powder (SLSP) in controlling cheese weed as compared to the untreated pots (control). The inhibitory response of weed growth increased by increasing the applied rates of BLSP or SLSP. Treatments of BLSP at $25 \mathrm{~g}$, SLSP at $25 \mathrm{~g}$, BLSP at $20 \mathrm{~g}$ and BLSP at $15 \mathrm{~g} / \mathrm{kg}$ soil, respectively, recorded the highest decrease in dry weight of cheese weed at 40 DAS by 92.90 , $89.03,86.13$ and $68.06 \%$, when compared to mixed control, while the reduction in the same parameter due to the previous treatments at harvest reached to $95.19,91.72,90.38$ and $78.30 \%$, respectively comparing with mixed control. The minimum reduction was recorded at $(5 \mathrm{~g} / \mathrm{kg}$ soil) of both materials as compared to the mixed control.

Table 1: Fresh and dry weight of cheese weed associated faba bean plants as affected by bitter and sweet lupine seed powder treatments (Average of the two seasons)

\begin{tabular}{ccccccc}
\hline Treatments & $\begin{array}{c}\text { Rate } \\
\text { (g/kg soil) }\end{array}$ & \multicolumn{2}{c}{ At 40 DAS } & \multicolumn{2}{c}{ At harvest } \\
\cline { 3 - 7 } Cheese weed alone & $\mathbf{0}$ & 12.34 & 3.92 & 37.34 & 11.25 \\
\hline Cheese weed +faba bean & $\mathbf{0}$ & 10.96 & 3.10 & 26.25 & 8.94 \\
\hline & & $\mathbf{5}$ & 7.94 & 2.45 & 16.43 & 5.18 \\
& bitter & $\mathbf{1 0}$ & 6.50 & 1.91 & 13.55 & 3.62 \\
Cheese & lupine seed & $\mathbf{1 5}$ & 2.84 & 0.99 & 5.46 & 1.94 \\
weed + & powder & $\mathbf{2 0}$ & 1.65 & 0.43 & 3.27 & 0.86 \\
faba bean & & $\mathbf{2 5}$ & 0.68 & 0.22 & 1.39 & 0.43 \\
& & $\mathbf{5}$ & 8.27 & 2.62 & 18.46 & 5.96 \\
& sweet & $\mathbf{1 0}$ & 7.39 & 2.41 & 14.29 & 4.75 \\
& lupine seed & $\mathbf{1 5}$ & 6.34 & 1.81 & 12.34 & 3.47 \\
& powder & $\mathbf{2 0}$ & 4.26 & 1.33 & 8.57 & 2.66 \\
& & $\mathbf{2 5}$ & 1.33 & 0.34 & 2.83 & 0.74 \\
\hline LSD at 5\% & & & 0.89 & 0.72 & 1.77 & 0.81 \\
\hline
\end{tabular}




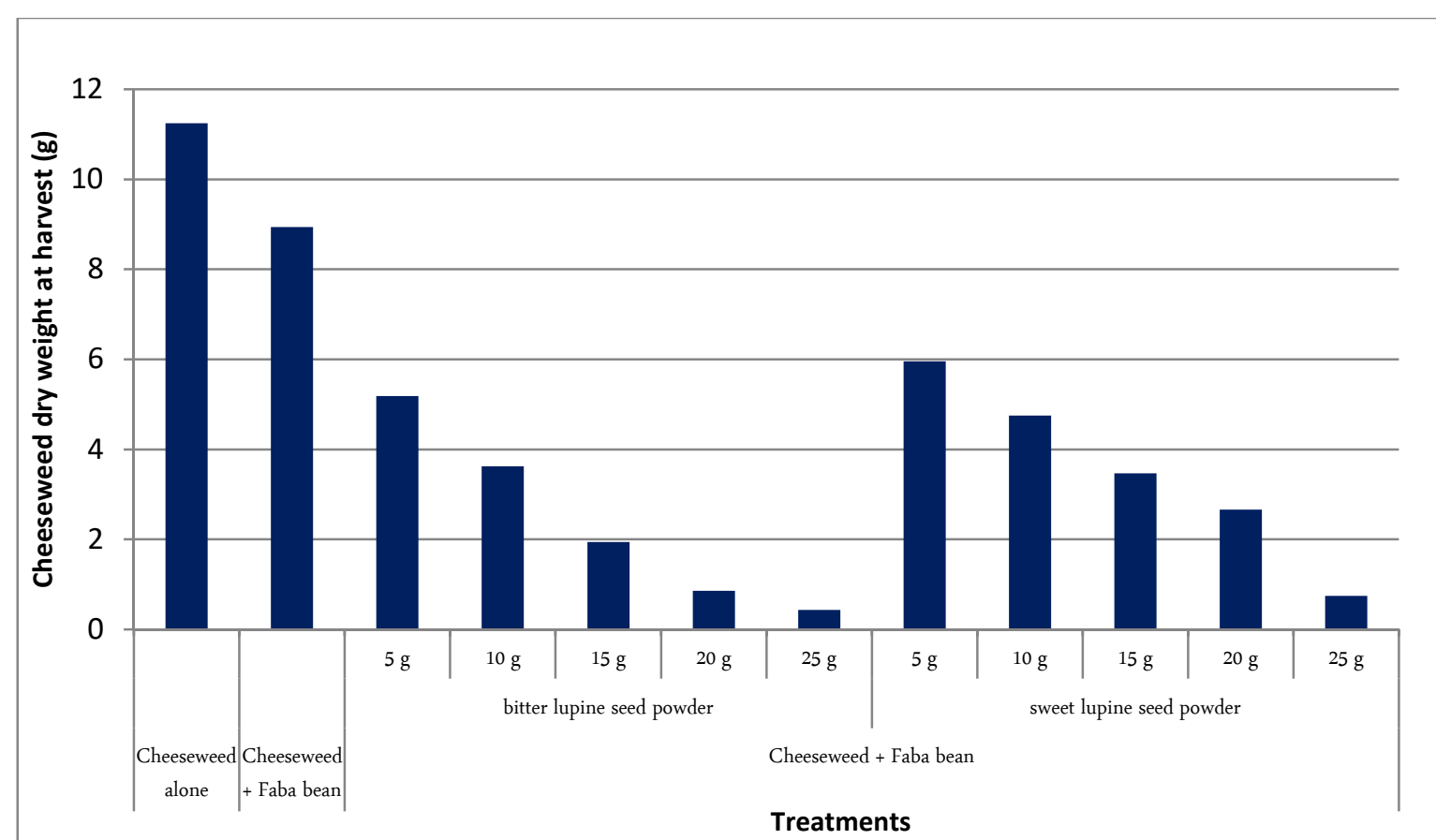

Fig. 1: Effect of bitter and sweet lupine seed powder on dry weight of cheese weed associated faba bean plants at harvest

\subsection{Faba bean growth}

The results in Table (2) cleared that after 40 DAS most growth characters of faba bean increased significantly with all treatments of both BLSP and SLSP over the unweeded control. The highest increase in the growth characters of faba bean were observed with the highest rate of $25 \mathrm{~g}$ BLSP followed by SLSP at $25 \mathrm{~g}$ and BLSP at $20 \mathrm{~g} / \mathrm{kg}$ soil, respectively as compared to other treatments.

Table 2: Growth parameters of faba bean plants as affected by bitter and sweet lupine seed powder at 40 days after sowing (Average of the two seasons).

\begin{tabular}{|c|c|c|c|c|c|c|c|}
\hline \multirow{2}{*}{\multicolumn{2}{|c|}{ Treatments }} & \multirow[b]{2}{*}{$\begin{array}{c}\text { Rate } \\
\text { (g/kg soil) }\end{array}$} & \multicolumn{5}{|c|}{ Growth parameters } \\
\hline & & & $\begin{array}{c}\text { Plant } \\
\text { height } \\
\text { (cm) }\end{array}$ & $\begin{array}{l}\text { No. of } \\
\text { leaves } \\
\text { /plant } \\
\end{array}$ & $\begin{array}{c}\text { No. of } \\
\text { branches } \\
\text { / plant }\end{array}$ & $\begin{array}{c}\text { F.W./ } \\
\text { plant } \\
\text { (g) }\end{array}$ & $\begin{array}{c}\text { D.W./ } \\
\text { plant (g) }\end{array}$ \\
\hline \multicolumn{2}{|c|}{ Faba bean alone } & $\mathbf{0}$ & 37.3 & 15.33 & 2.00 & 19.83 & 2.35 \\
\hline \multicolumn{2}{|c|}{ Faba bean + cheese weed } & $\mathbf{0}$ & 31.8 & 10.20 & 1.13 & 12.50 & 1.04 \\
\hline \multirow{5}{*}{$\begin{array}{l}\text { Faba bean + } \\
\text { cheese weed }\end{array}$} & \multirow{5}{*}{$\begin{array}{l}\text { bitter lupine } \\
\text { seed powder }\end{array}$} & 5 & 34.7 & 11.80 & 1.50 & 15.48 & 1.70 \\
\hline & & 10 & 35.9 & 12.70 & 1.66 & 17.00 & 2.10 \\
\hline & & 15 & 38.4 & 16.60 & 2.15 & 20.10 & 2.53 \\
\hline & & 20 & 39.1 & 17.60 & 2.25 & 20.25 & 2.72 \\
\hline & & 25 & 43.0 & 20.50 & 2.50 & 21.50 & 3.31 \\
\hline \multirow{5}{*}{$\begin{array}{l}\text { Faba bean + } \\
\text { cheese weed }\end{array}$} & \multirow{5}{*}{$\begin{array}{l}\text { sweet lupine } \\
\text { seed powder }\end{array}$} & 5 & 33.5 & 11.40 & 1.50 & 14.33 & 1.61 \\
\hline & & 10 & 35.2 & 12.00 & 1.66 & 16.50 & 1.84 \\
\hline & & 15 & 36.4 & 13.20 & 1.80 & 17.90 & 2.15 \\
\hline & & 20 & 36.7 & 14.50 & 1.80 & 18.67 & 2.21 \\
\hline & & 25 & 41.0 & 19.00 & 2.50 & 20.55 & 2.96 \\
\hline LSD at 5\% & & & 1.66 & 1.40 & 0.52 & 1.26 & 0.56 \\
\hline
\end{tabular}

At 95 DAS, the results in Table (3) illustrated that all the treatments increased significantly all growth characters of faba bean except number of branches/plant as compared to the mixed control. The growth characters increased by increasing the rate of both allelopathic materials used. In this respect, BLSP treatments showed more effective than SLSP on faba bean plants as compared to the untreated control. Treatments of $25 \mathrm{~g}$ BLSP followed by SLSP at $25 \mathrm{~g}$ and BLSP at $20 \mathrm{~g} / \mathrm{kg}$ soil, respectively achieved the maximum increase in all growth characters in the two growth ages as compared to the corresponding 
free controls. At 40 DAS, the previous treatments increased faba bean dry weight by 40.85, 25.96 and $15.74 \%$ over the free control, while at 95 DAS these increases with the same character reached respectively to $36.31,24.40$ and $3.57 \%$ over the free control. On the other side, mixed control gave the lowest values of all growth parameters of faba bean plants at the two ages of growth.

Table 3: Growth parameters of faba bean plants as affected by bitter and sweet lupine seed powder at 95 days after sowing (Average of the two seasons)

\begin{tabular}{|c|c|c|c|c|c|c|c|}
\hline \multirow{2}{*}{ Treatments } & & \multirow[b]{2}{*}{$\begin{array}{c}\text { Rate } \\
\text { (g/kg soil) }\end{array}$} & \multicolumn{5}{|c|}{ Growth parameters } \\
\hline & & & $\begin{array}{c}\text { Plant } \\
\text { height } \\
(\mathrm{cm})\end{array}$ & $\begin{array}{l}\text { No. of } \\
\text { leaves } \\
\text { /plant }\end{array}$ & $\begin{array}{c}\text { No. of } \\
\text { branches } \\
\text { / plant } \\
\end{array}$ & $\begin{array}{c}\text { F.W./ } \\
\text { plant } \\
\text { (g) }\end{array}$ & $\begin{array}{c}\text { D.W./ } \\
\text { plant } \\
(g)\end{array}$ \\
\hline Faba bean alone & & 0 & 71.7 & 27.0 & 3.33 & 64.80 & 8.40 \\
\hline Faba bean + che & eed & 0 & 53.2 & 19.2 & 2.10 & 43.94 & 3.66 \\
\hline \multirow{5}{*}{$\begin{array}{l}\text { Faba bean }+ \\
\text { cheese weed }\end{array}$} & \multirow{5}{*}{$\begin{array}{l}\text { bitter lupine } \\
\text { seed powder }\end{array}$} & 5 & 60.9 & 22.8 & 2.75 & 59.75 & 6.66 \\
\hline & & 10 & 64.5 & 25.4 & 3.00 & 60.72 & 7.27 \\
\hline & & 15 & 66.7 & 28.8 & 3.50 & 63.33 & 7.97 \\
\hline & & 20 & 72.0 & 31.2 & 3.66 & 71.27 & 8.70 \\
\hline & & 25 & 83.0 & 32.7 & 3.67 & 74.45 & 11.45 \\
\hline \multirow{5}{*}{$\begin{array}{l}\text { Faba bean }+ \\
\text { cheese weed }\end{array}$} & \multirow{5}{*}{$\begin{array}{l}\text { sweet lupine } \\
\text { seed powder }\end{array}$} & 5 & 56.8 & 21.1 & 2.50 & 49.83 & 4.83 \\
\hline & & 10 & 59.4 & 21.9 & 2.60 & 52.75 & 4.98 \\
\hline & & 15 & 63.0 & 24.1 & 2.88 & 60.28 & 7.14 \\
\hline & & 20 & 65.8 & 26.3 & 3.10 & 61.43 & 7.62 \\
\hline & & 25 & 74.7 & 29.6 & 3.60 & 72.55 & 10.45 \\
\hline LSD at $5 \%$ & & & 2.2 & 1.7 & 0.80 & 1.46 & 0.98 \\
\hline
\end{tabular}

\subsection{Faba bean yield and yield components}

Yield and yield components of faba bean plant represented by number of pods/plant, number of seeds/pod, weight of dry pods/plant, weight of seeds/plant as well as weight of 100 seeds (Table 4) and Fig. (2) were significantly increased by using all applied rates $(5-25 \mathrm{~g} / \mathrm{kg}$ soil) of BLSP or SLSP except the number of seeds/pod at the lowest rate $(5 \mathrm{~g} / \mathrm{kg}$ soil) of both applied materials as compared to corresponding mixed controls. Most faba bean yield components increased by increasing the rate of materials used (BLSP or SLSP).

Table 4: Yield and yield components of faba bean plants as affected by bitter and sweet lupine seed powder at harvest (Average of the two seasons)

\begin{tabular}{|c|c|c|c|c|c|c|c|}
\hline \multirow{2}{*}{\multicolumn{2}{|c|}{ Treatments }} & \multirow[b]{2}{*}{$\begin{array}{c}\text { Rate } \\
\text { (g/kg soil) }\end{array}$} & \multicolumn{5}{|c|}{ Yield and yield components parameters } \\
\hline & & & $\begin{array}{l}\text { No. of } \\
\text { pods/ } \\
\text { plant }\end{array}$ & $\begin{array}{c}\text { No. of } \\
\text { seeds / } \\
\text { pod }\end{array}$ & $\begin{array}{c}\text { Wt. of Dry } \\
\text { pods/plant } \\
\text { (g) }\end{array}$ & $\begin{array}{c}\text { Wt. of } \\
\text { seeds/ } \\
\text { plant (g) }\end{array}$ & $\begin{array}{l}\text { Wt. of } \\
100 \\
\text { seeds } \\
(\mathrm{g})\end{array}$ \\
\hline \multicolumn{2}{|c|}{ Faba bean alone } & 0 & 7.66 & 3.66 & 19.87 & 9.48 & 85.44 \\
\hline \multicolumn{2}{|c|}{ Faba bean + cheese weed } & 0 & 3.75 & 2.35 & 9.72 & 6.27 & 53.57 \\
\hline \multirow{5}{*}{$\begin{array}{l}\text { Faba bean }+ \\
\text { cheese weed }\end{array}$} & \multirow{5}{*}{$\begin{array}{l}\text { bitter lupine } \\
\text { seed powder }\end{array}$} & 5 & 6.33 & 3.00 & 11.63 & 7.50 & 73.53 \\
\hline & & 10 & 6.75 & 3.33 & 12.52 & 7.71 & 77.42 \\
\hline & & 15 & 7.53 & 3.54 & 18.73 & 9.17 & 82.98 \\
\hline & & 20 & 7.64 & 3.65 & 19.56 & 9.39 & 84.56 \\
\hline & & 25 & 8.92 & 4.37 & 25.02 & 12.04 & 90.63 \\
\hline \multirow{5}{*}{$\begin{array}{l}\text { Faba bean }+ \\
\text { cheese weed }\end{array}$} & \multirow{5}{*}{$\begin{array}{l}\text { sweet lupine } \\
\text { seed powder }\end{array}$} & 5 & 5.44 & 2.76 & 11.00 & 7.36 & 69.63 \\
\hline & & 10 & 6.48 & 3.23 & 12.15 & 7. 39 & 77.14 \\
\hline & & 15 & 7.16 & 3.33 & 14.13 & 7.98 & 79.88 \\
\hline & & 20 & 7.34 & 3.36 & 16.55 & 8.81 & 81.22 \\
\hline & & 25 & 8.55 & 4.10 & 23.70 & 10.83 & 88.32 \\
\hline LSD at $5 \%$ & & & 1.04 & 0.88 & 1.27 & 1.09 & 1.74 \\
\hline
\end{tabular}

The maximum increase in all yield components recorded with the highest rate $(25 \mathrm{~g} / \mathrm{kg}$ soil) of BLSP or SLSP over the corresponding free control. The increases of weight of seeds $/$ plant with $25 \mathrm{~g} / \mathrm{kg}$ soil BLSP or SLSP reached respectively to $27.01 \%$ and $14.24 \%$ over their free control, while, the 
increases of the weight of 100 seeds with same treatments recorded $6.10 \%$ and $3.73 \%$ over the free control. It is obvious from the results of the above two yield characters that BLSP at $25 \mathrm{~g} / \mathrm{kg}$ soil rate achieved increases above the corresponding healthy control reach near to the double of that recorded with the same SLSP rate on the same yield character.

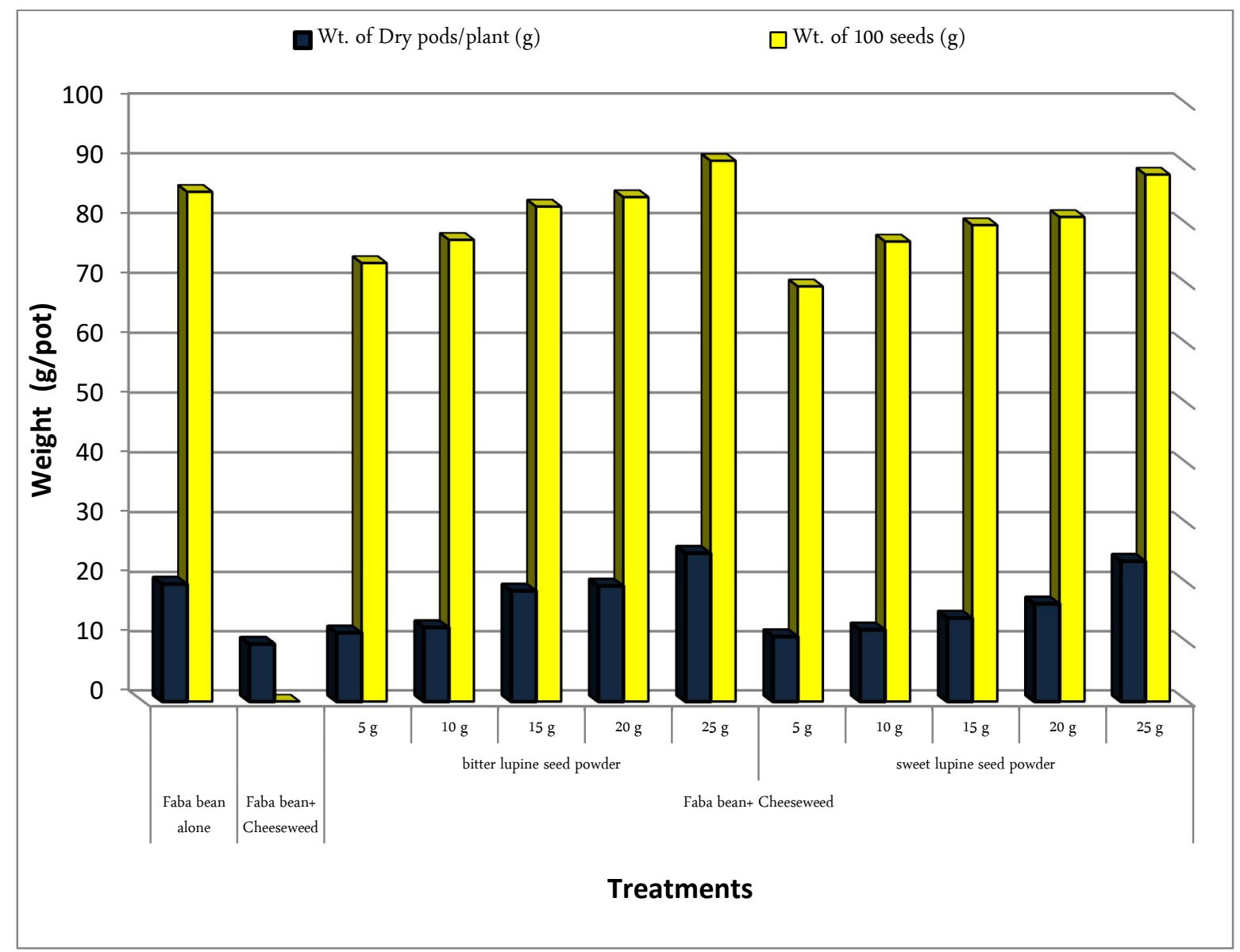

Fig. 2: Effect of bitter and sweet lupine seed powder on wt. of dry pods/plant (g) and wt. of 100-seed (g) of faba bean

\subsection{Total phenols, flavonoids and alkaloids in lupine seed powder}

The results in Table (5) show that the content of both phenolic and flavonoids compounds in BLSP were higher than that of SLSP. It is worthy to mention that the total alkaloids in BLSP were many folds than that in SLSP.

Table 5: Total phenols, flavonoids and alkaloids in both sweet and bitter seeds of lupines

\begin{tabular}{cccc}
\hline Lupine seeds & $\begin{array}{c}\text { Total phenols as mg/100g } \\
\text { dry weight }\end{array}$ & $\begin{array}{c}\text { Total flavonoids as mg } \\
\text { /100g dry weight }\end{array}$ & $\begin{array}{c}\text { Total alkaloids mg/g } \\
\text { dry weight }\end{array}$ \\
\hline Sweet & 129.36 & 29.04 & 0.648 \\
Bitter & 170.44 & 40.94 & 20.700 \\
\hline
\end{tabular}

\section{Discussion}

There is no doubt that controlling weeds using a safety environmental method in one of the most important feeding crops in Egypt, such as faba bean would be advantage.

The results of the present study clearly showed that the seed powder of bitter or sweet lupine significantly reduced fresh and dry weight of the associated cheese weed and this effect remained till harvest (Table 1). These results could be due to lupine allelochemicals effect mainly total phenols, flavonoids and alkaloids contents (Table 5). Lupine alkaloids have been suggested as the biologically substances responsible for the phytotoxicity (Tahara et al., 1984).Also, it is worthy to mention that use 
of high alkaloid content cultivars of white lupine enhanced weed suppressive ability; Wink, 1983; Muzquiz et al., 1994 and Zou et al., 2014. Our results add more support to the findings of Ferreira and Reinhardt (2010). In this connection it is worthy to mention that several workers reported that the decomposition of some allelopathic plants residues releases allelochemicals which are capable in controlling the growth of several associating weeds. Khanh et al., (2005) also, reported that some leguminous plants have the possibility of releasing allelochemicals from their roots as well as from the decomposition of their residues.

Moreover, Stobiecki et al., (1993) isolated phenolic compounds from bitter lupine seeds which caused inhibition to lettuce seedlings growth (Kwee and Niemeyer, 2011; Roby et al., 2013 and ElRokiek et al., 2018). The present work add more support to these results since the amount of phenolic compounds, flavonoids and alkaloids in the seed powder of BLSP is higher than those present in SLSP cultivar.

In addition, it must be mentioned that beside the inhibiting influence of the seed powder of both lupine cultivars (BLSP) and (SLSP), in controlling cheese weed associating faba bean plants, a pronounced enhancement in faba bean growth occurred which caused an increase in its yield and yield components (Tables 3and 4).

It is worthy to mention that, the allelopathic effect of lupine seed powder(BLSP) or (SLSP) in improving faba bean growth and increasing its yield and yield components not only due to the inhibition of cheese weed growth that increase the competitive ability of the plant, but also could be due to the selectivity of the allelochemicals in their action and the plants in their responses (Einhellig, 1995).Allelochemicals which inhibit the growth of some species at certain concentration may stimulate the growth of same or different species at different concentrations (Ahmed et al., 2014 \& 2016; Messiha et al., 2013 \& 2018; Baeshen, 2014 and El-Masry et al., 2015 \& 2019).

\section{Conclusion}

The results of this work showed the possibility of using Lupinus albus seed powder as a safe bioherbicide environmental method to control Malva parviflora weed associated Vicia faba plant which is one of most feeding crops in Egypt.

\section{References}

Ahmed, S.A.A., R.R. El-Masry, N.K. Messiha and K.G. El-Rokiek, 2018. Evaluating the allelopathic efficiency of the seed powder of Raphanus sativus L. in controlling some weeds associating Phaseolus vulgaris L. International Journal of Environment, 7(3):87-94.

Ahmed, S.A., K.G. El-Rokiek, R.R. El-Masry and N.K. Messiha, 2014. The Efficiency of Allelochemicals in The Seed Powder of Eruca sativa In Controlling Weeds in Pisum sativum. Middle East Journal of Agriculture Research, 3(4): 757-762.

Ahmed, S.A.A., N.K. Messiha, K.G. El- Rokiek, S.A. Mohamed and R.R. El-Masry, 2016. The allelopathic efficiency of two Brassicaceae plant seeds in controlling weeds associating sunflower plants. Res. J. of Pharm., Biol. and Chem. Sci. Sept.-Oct., 7(5): 158-165.

Ahmed, S.A.A., N.K. Messiha, R.R. El-Masry and M.A.T. El-Dabaa, 2020.The dual allelopathic capacity of two Brassicaceae plants seed powder in controlling Orobanche crenata infesting Pisum sativum as well as stimulating its growth and yield. Bulletin of the National Research Centre, 1-8 https:// doi.org/10.1186/s42269-020-0276-6-x.

Baeshen, A.A., 2014. Morphological and elements constituent effects of allelopathic activity of some medicinal plants extracts on Zea mays. Int. Curr. Res. Aca. Rev., 2(4):135-145.

Bell, E.A. and B.V. Charlwood, ed., 1980. Encyclopedia of Plant Physiology, Volume8.Secondary Plant Products. Springer-Verlag, New York 674.

Dixon, R.A. and C.J. Lamb, 1990. Molecular communication in interactions between plants and microbial pathogens. Annu. Rev. Plant Physiol. Plant Mol. Biol., 41: 339 - 367.

Duke, S. O., F.E. Fedayan, J.G. Romagni and A.M. Rimando, 1999. Natural Products as sources of herbicides: current status and future trends. Weed Res., 40: 99-111.

Einhellig, F.A., 1995. Mechanism of Action of Allelochemical in Allelopathy. In: Allelopathy Organisms, Processes and Application. Am. Chem. Soc., Washington, USA, 96-116. 
Einhellig, F.A., 2002. The physiology of allelochemical action: clues and views. Pp.1-23 In:

Allelopathy, from Molecules to Ecosystems, Reigos M.J., PedrolN.Eds.Science Publishers, Enfield, New Hampshire.

El-Daly, F.A. and M.H. Soliman, 1997. Effect of Different Concentrations of Lupine seed Extract on the Growth Criteria and Pigmentation of Soybean Plant at Different Growth Stages. Egypt. J. Physiol. Sci., 21(2): $187-196$.

El-Masry, R.R., S.A.A. Ahmed, K.G. El- Rokiek, N.K. Messiha and S.A. Mohamed, 2019. Allelopathic activity of the leaf powder of Ficus nitida on the growth and yield of Vicia faba and associated weeds. Bulletin of the National Research Centre, 1-7. http:// doi.org/10.1186/s42269-019-0114-x

El-Masry, R.R., N.K. Messiha, K.G. El- Rokiek, S.A. Ahmed and S.A. Mohamed, 2015. The Allelopathic Effect of Eruca sativa Mill. Seed Powder on Growth and Yield of Phaseolus vulgaris and Associated Weeds. Current Sciences International, 4(4):485-490.

El-Rokiek, K.G., I.M. El-Metwally, N.K. Messiha and S.A. Saad El-Din, 2015. Controlling Orobanche crenata in Faba bean using the Herbicides Glyphosate and Imazapic with some additives. International Journal of Chem. Tech. Research, 8(10): 18-26.

El-Rokiek, K.G., S.A. Saad El-Din, M.A. El-Wakeel, M.G. Dawood and M.E. El-Awadi, 2018. Allelopathic effect of the two medicinal plants (Plectranthusam boinicus, Lour.) and Ocimum basilicum L. on the growth of Pisum sativum L. and associated weeds. Middle East Journal of Agriculture Research, 07(3): 1146-1153.

Ferreira, M.I. and C.F. Reinhardt, 2010. Field assessment of crop residues for allelopathic effects on both crops and weeds. Agronomy Journal, 102:1593-1600.

Harborne, J.B., 1977. Chemosystematics and coevolution. Pure Appl. Chem., 49:1403 - 1421.

Harborne, J.B., 2005. Phytochemical methods - A guide to modern techniques of plant analysis.3rd edition. Springer Pvt. Ltd., New Delhi.

Hussein, H.F., 2001. Estimation of critical period of crop-weed competition and nutrient removal by weeds in onion, (Allium cepa, L.) in sandy soil. Egypt. J. Agron. 24: 43-62.

Ingham, J. L., 1982. Phytoalexins from Leguminosae. In "Phytoalexins" eds. Bailey, J. A. and Mansfield, J. W., Blackie \&Son Ltd., Glasgow, UK, 21 -80.

Khanh, T.D., M.I. Chung, T.D. Xuan and S. Tawata, 2005.The exploitation of crop allelopathy in sustainable agricultural production. J. Agron. Crop Sci., 191:172-184.

Kwee, E.M. and E.D. Niemeyer, 2011.Variations in phenolic composition and antioxidant properties among 15 basil, (Ocimum basilicum L.) cultivars. Journal of Food Chemistry, 128(4):1044-1050.

Mahmood, A. and Z.A. Cheema, 2004. Influence of sorghum mulch on purple nutsedge, (Cyperus Rotundus L.) Int. J. Agric. \& Biol., 6(1): 86-88.

Manikandan, M. and M. Jayakumar, 2011. Herbicidal effect of Ficus bengalensis on Ipomoea pentaphylla. Int. Med Arom Plants, 1(2):128-131.

Messiha, N.K., 2005. Effect of different concentrations of Lupine seed extract on growth, yield, yield components and chemical composition of mungbean and the two weeds Jew's mallow and purslane. J. Agric. Sci. Mansoura Univ., 30 (3): 1381 - 1390.

Messiha, N.K., M.A.T. El-Dabaa, R.R. El-Masry and S.A.A. Ahmed, 2018. The allelopathic influence of Sinapis alba seed powder, white mustard) on the growth and yield of Vicia faba, faba bean) infected with Orobanche crenata, broomrape. Middle East Journal of Applied Sciences, 8(2):418425.

Messiha, N.K., S.A. Ahmed, K.G. El-Rokiek, M.G. Dawood and R.R. El-Masry, 2013. The Physiological Influence of Allelochemicals in Two Brassicaceae Plant Seeds on the Growth and Propagative Capacity of Cyperus rotundus and Zea mays L. World Appl. Sci. J., 26(9): 1142-1149.

Mohsin, N., M. Tariq, M.J. Zaki, M.W. Abbasi and M. Imran, 2016. Allelopathic effect of Ficus bengalensis L. leaves extract on germination and early seedling growth of maize, mungbean and sunflower. Int. J. Biol. Res., 4(1): 34-38.

Muzquiz, M., C. de la Cuadrado, C. Burbano and R. Calvo, 1994. Herbicide-like effect of Lupinus alkaloids. Industrial Crops and Products, 2: 273-280.

Rice, E. L., 1984. In Allelopathy, 2nd ed., Academic Press Orlando; FL. 422. 
Roby, M.H.H., M.A., Sarhan, K.A. Selim and K.I. Khalel, 2013. Evaluation of antioxidant activity, total phenols and phenolic compounds in thyme, Plectranthus amboinicus(Lour.) L.), sage, (Salvia officinalisL.), and marjoram, (Origanum majorana L.) extracts. Industrial Crops and Products, 43 : 827-831.

Snedecor, G.W. and W.G. Cochran, 1980. Statistical Methods. 7th Ed., 507. The Iowa State Uni. PRESS, Ames, Iowa.

Srisawat, U., W. Panuto, N. Kaendee, S. Tanuchit, A. Itharat, N. Lerdvuthisopon and P. Hansaku, 2010. Determination of phenolic compounds, flavonoids, and antioxidant activities in water extracts of Thai red and white rice cultivars. J Med Assoc. Thailand, 93(7): S83-S91.

Stobiecki, M., D. Ciesiotka, M. Peretiatkowicz and K. Gulewicz, 1993. Phenolic compounds isolated from bitter lupine seeds and their inhibitory effects on germination and seedling growth of lettuce. Journal of Chemical Ecology, 19(2): 325-338.

Sujak, A., A. Kotlarz and W. Strobel, 2006. Compositional and nutritional evaluation of several lupine seeds. Food Chem., 98: 711-719.

Tahara, S., J.L. Ingham, S. Nakahara, J. Mizutani and J.B. Harborne, 1984. Fungitoxic dihydrofuranoisoflavones and related compounds in white lupine, Lupinus albus. Phytochemistry, 23: $1889-1900$.

Velasco, P., P. Soengas, M. Vilar and M.E. Cartea, 2008. Comparison of glucosinolate profiles in leaf and seed tissues of different Brassica napus crop. J. Amer. Soc. Hort. Sci., 133(4): 551-558.

White, R.H., A.D. Worsham and U.D.O. Blum, 1989. Allelopathic Potential of Legume Debris and Aqueous Extracts. Weed Science, 37: $674-679$.

Wink, M., 1983. Inhibition of seed germination by quinolizidine alkaloids - Aspects of allelopathy in Lupinusalbus L. Planta, 158: 365-268.

Zeidan, M.S., 2002.Effect of sowing dates and urea foliar application on growth and seed yield of determinate faba bean, (Vicia faba L.) under Egyptian conditions. Egypt J. Agron., 24:93-102.

Zou, L., A. Santanen, B. Tein, L. Frederick, Stoddard and P.S.A. Makela, 2014. Interference potential of buckwheat, faba bean, oilseed hemp, vetch, white lupine and caraway to control couch grass weed. Allelopathy Journal, 33(2): 227-236. 